\title{
RADIOCARBON VARIATIONS FROM TASMANIAN CONIFERS: FIRST RESULTS FROM LATE PLEISTOCENE AND HOLOCENE LOGS
}

\author{
MIKE BARBETTI ${ }^{1}$, TREVOR BIRD ${ }^{2}$, GEORGE DOLEZAL ${ }^{1}$, GILLIAN TAYLOR ${ }^{1}$ \\ ROGER FRANCEY $Y^{3}$ EDWARD COOK ${ }^{4}$ and MIKE PETERSON ${ }^{5}$
}

\begin{abstract}
Dendrochronological studies have begun on two conifer species in the Stanley River area of western Tasmania. The chronology extends to $273 \mathrm{BC}$ for Huon pine (Lagarostrobos franklinii) and to AD 1450 for celery-top pine (Phyllocladus aspleniifolius). Apart from living or recently felled trees, sections have been taken from 58 logs preserved in floodplain sediments. Two of these logs have late Pleistocene ages, centered around 13.0 and $12.7 \mathrm{k}{ }^{14} \mathrm{C}$ yr BP. Four logs are between 8 and $9 \mathrm{ka} \mathrm{BP}$, and one is centered at $7.3 \mathrm{ka} \mathrm{BP}$. The remaining logs have various ages between $6.2 \mathrm{ka} \mathrm{BP}$ and the present. ${ }^{14} \mathrm{C}$ measurements have been performed on decadal samples from the two late Pleistocene logs, providing short (260-yr) records of atmospheric ${ }^{14} \mathrm{C}$ variations when plotted against individual ring numbers. Decadal measurements on the 7300-yr-old log have been wiggle-matched with ${ }^{14} \mathrm{C}$ calibration curves from German oak and bristlecone pine. Measurements for the period, AD 1600-1800, show good agreement with northern hemisphere results, and a nearly zero offset between the hemispheres.
\end{abstract}

\section{INTRODUCTION}

Radiocarbon calibration is now well established for most of the Holocene. The differences between tree-ring ages and conventional ${ }^{14} \mathrm{C}$ ages have been determined for the last 9700 calendar yr by precision ${ }^{14} \mathrm{C}$ measurements on 10 - or 20 -ring samples, which are independently dated by dendrochronology (summarized by Stuiver et al. 1991). A small part of the difference occurs because ${ }^{14} \mathrm{C}$ ages are, by international agreement, calculated using a half-life of $5568 \mathrm{yr}$, which is known to be about 3\% too short. Differences apart from this 3\% reflect variations in the production rate and in the exchange of ${ }^{14} \mathrm{C}$ between oceans, atmosphere and biosphere. Most of the Holocene variation is thought to be due to changes in the production rate; the long-term peak-to-trough change is attributed to changes in the Earth's magnetic field strength, which affect the cosmic-ray flux, whereas shorter-term wiggles (with amplitudes of 100 or $200 \mathrm{yr}$ ) are attributed to solar modulation of the cosmic-ray flux.

Early Holocene ${ }^{14} \mathrm{C}$ data from southern Germany (Becker \& Kromer 1986) are from a floating tree-ring sequence. They show short-term wiggles, such as those seen in recent millennia, and also a horizontal trend in the calibration curve with nearly constant ${ }^{14} \mathrm{C}$ ages (9600 BP) over several hundred tree rings.

Southern hemisphere measurements are essential as an independent verification, and are important because the offset from the northern hemisphere (36 yr in recent centuries; Lerman, Mook \& Vogel 1970; Vogel et al. 1986) may have varied in earlier times due to changes in global carbon fluxes.

We began dendrochronological studies 10 years ago on two conifer species in the Stanley River area of western Tasmania $\left(145^{\circ} \mathrm{E}, 42^{\circ} \mathrm{S}\right.$; Francey et al. 1984). The chronology for Huon pine (Lagarostrobos franklinii) has recently been extended to $273 \mathrm{BC}$. Living celery-top pine (Phyllocladus aspleniifolius) trees are up to $500 \mathrm{yr}$ old. We sampled logs exposed in the river banks and

\footnotetext{
${ }^{1}$ The NWG Macintosh Centre for Quaternary Dating, Madsen Building F09, University of Sydney, Sydney NSW 2006 Australia

${ }^{2}$ Trades Hall, 219 New Town Road, New Town, Tasmania 7008 Australia

${ }^{3}$ CSIRO Division of Atmospheric Research, Private Bag No. 1, Mordialloc, Victoria 3195 Australia

${ }^{4}$ Lamont-Doherty Geological Observatory of Columbia University, Palisades, New York 10964 USA

${ }^{5}$ Forestry Commission, Hobart, Tasmania 7001 Australia
} 
excavated in floodplain sediments between 1981 and 1984, and obtained sections from 58 wellpreserved logs. The oldest are two celery-top logs with late Pleistocene ages, centered around 13.0 and $12.7 \mathrm{k}{ }^{14} \mathrm{C}$ yr BP. Four logs are between 8 and $9 \mathrm{ka}$, and one is centered at $7.3 \mathrm{ka} \mathrm{BP}$. The remaining logs have various ages between $6.2 \mathrm{ka} \mathrm{BP}$ and the present, but so far there are no logs between about 3.6 and $2.6 \mathrm{ka}$.

These discoveries in western Tasmania have given us an opportunity to make selected southern hemisphere comparisons with the $9.7 \mathrm{ka}$ (dendroyear) span of ${ }^{14} \mathrm{C}$ records obtained from northern hemisphere bristlecone pine and European oak (Stuiver et al. 1991).

\section{METHODOLOGY}

We polished cross-sections from the logs and split them into consecutive 10-ring samples; for the innermost and outermost parts, where the rings were narrow, we took up to 60 rings per sample. For the time span, AD 1600-1800, we used five-ring samples where possible. We reduced the wood samples to about $0.5 \mathrm{~mm}$ particle size in a cutting mill, and prepared holocellulose following the method of Head (1979). We used standard techniques (Gupta \& Polach 1985) to prepare benzene samples $(4 \mathrm{ml})$. Stable carbon isotope $\left({ }^{13} \mathrm{C} /{ }^{12} \mathrm{C}\right)$ measurements were made on subsamples of the combustion $\mathrm{CO}_{2}$ at the CSIRO Division of Atmospheric Research.

We made ${ }^{14} \mathrm{C}$ measurements using Teflon vials in a low-level Wallac Quantulus counter, usually with duplicate measurements in another counter (Wallac Rackbeta) linked to a multichannel analyzer and microcomputer system. A third counter (Packard Tri-Carb with fixed windows) was used for some measurements before February 1987, but most of the data were collected between 1987 and 1989. We calculated conventional ${ }^{14} \mathrm{C}$ ages using modern standard values derived from measurements of ANU sucrose and NBS oxalic acid, but we assumed an uncertainty of \pm 0.1 or \pm 0.2 counts $\mathrm{min}^{-1}$ for the standard, considerably larger than the typical Poisson deviation of \pm 0.07 counts $\mathrm{min}^{-1}$ associated with an individual standard measurement. We then combined the results from the counters, weighting them inversely by variance; age differences between the counters are indicated by $z$-statistic values. Measurement uncertainties associated with our combined results typically range from $c a . \pm 30 \mathrm{yr}$ for recent samples to $c a . \pm 60 \mathrm{yr}$ for late Pleistocene samples.

\section{RESULTS}

${ }^{14} \mathrm{C}$ results (Table 1) from the two late Pleistocene logs provide short $(260$-yr) records of atmospheric ${ }^{14} \mathrm{C}$ variations when plotted against individual ring numbers (Fig. 1). The variations from sample to sample are not always smooth, and may reflect a combination of experimental uncertainties (trace levels of contamination and random measurement errors). One ${ }^{14} \mathrm{C}$ result from the center of SRT-462, and two from the outermost rings of SRT-157 (probably sapwood), gave anomalously young results, which are excluded from Figure 1. The overall trend for SRT-462 is fairly flat, and the trend for SRT-157 is downward toward the outer rings. The two logs do not appear to overlap in time.

Results from the 7300-yr-old log SRT-444 (Table 2) can be compared with ${ }^{14} \mathrm{C}$ calibration curves from German oak and bristlecone pine (Fig. 2). Since SRT-444 is not dated by dendrochronology, we sought to position it by ${ }^{14} \mathrm{C}$ wiggle-matching. We estimated decadal values for German oak by a combination of averaging (for cases of multiple measurements per decade) and interpolation (for decades without data). Three of the SRT-444 values that did not correspond exactly to decadal spacing were taken as representing the nearest decadal sample. We used these smoothed values and calculated root mean square (rms) differences, moving the zero-point of the SRT-444 data in decadal steps. The minimum rms difference occurred with ring 0 of SRT-444 placed at 8260 den- 


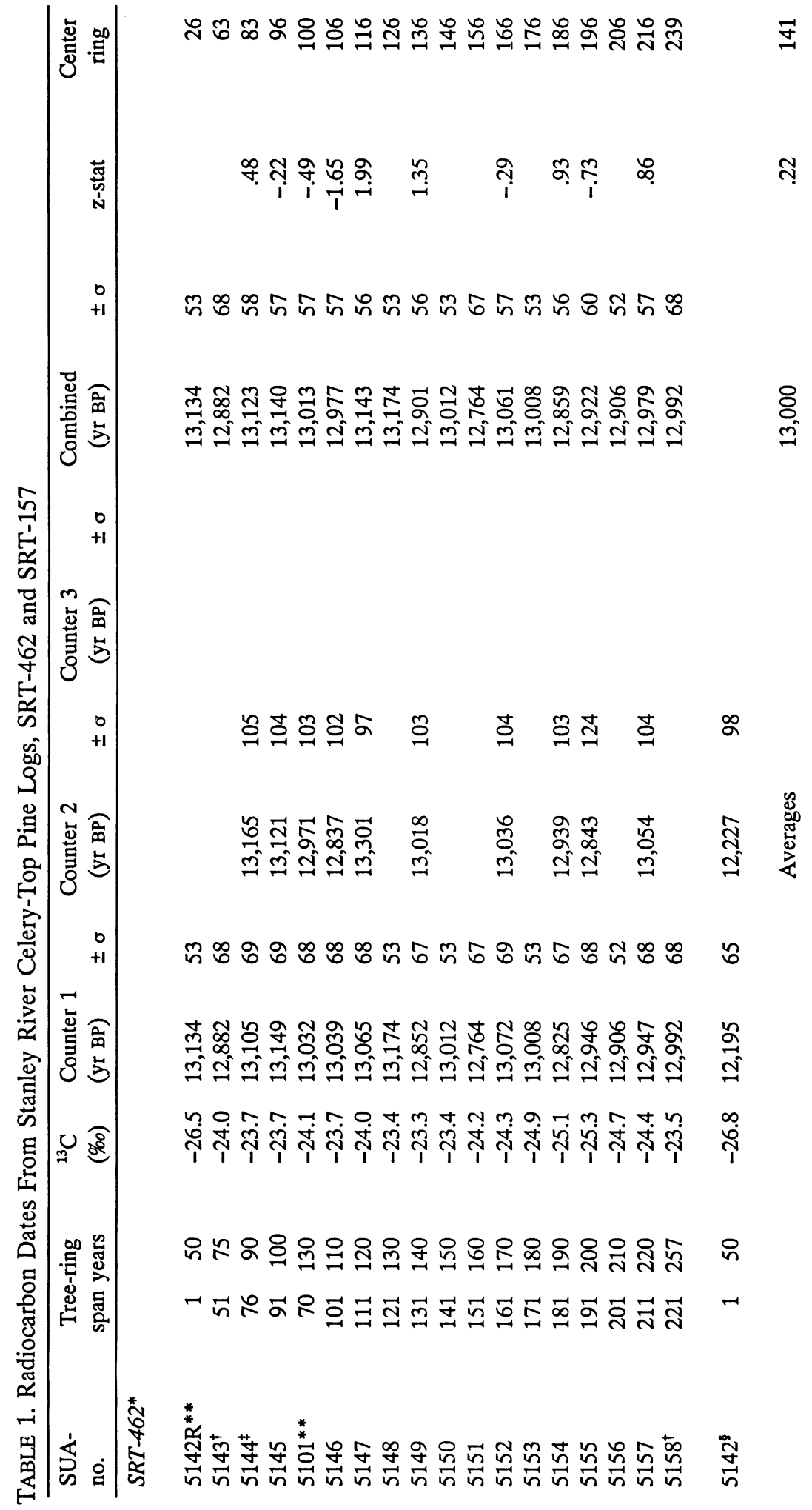




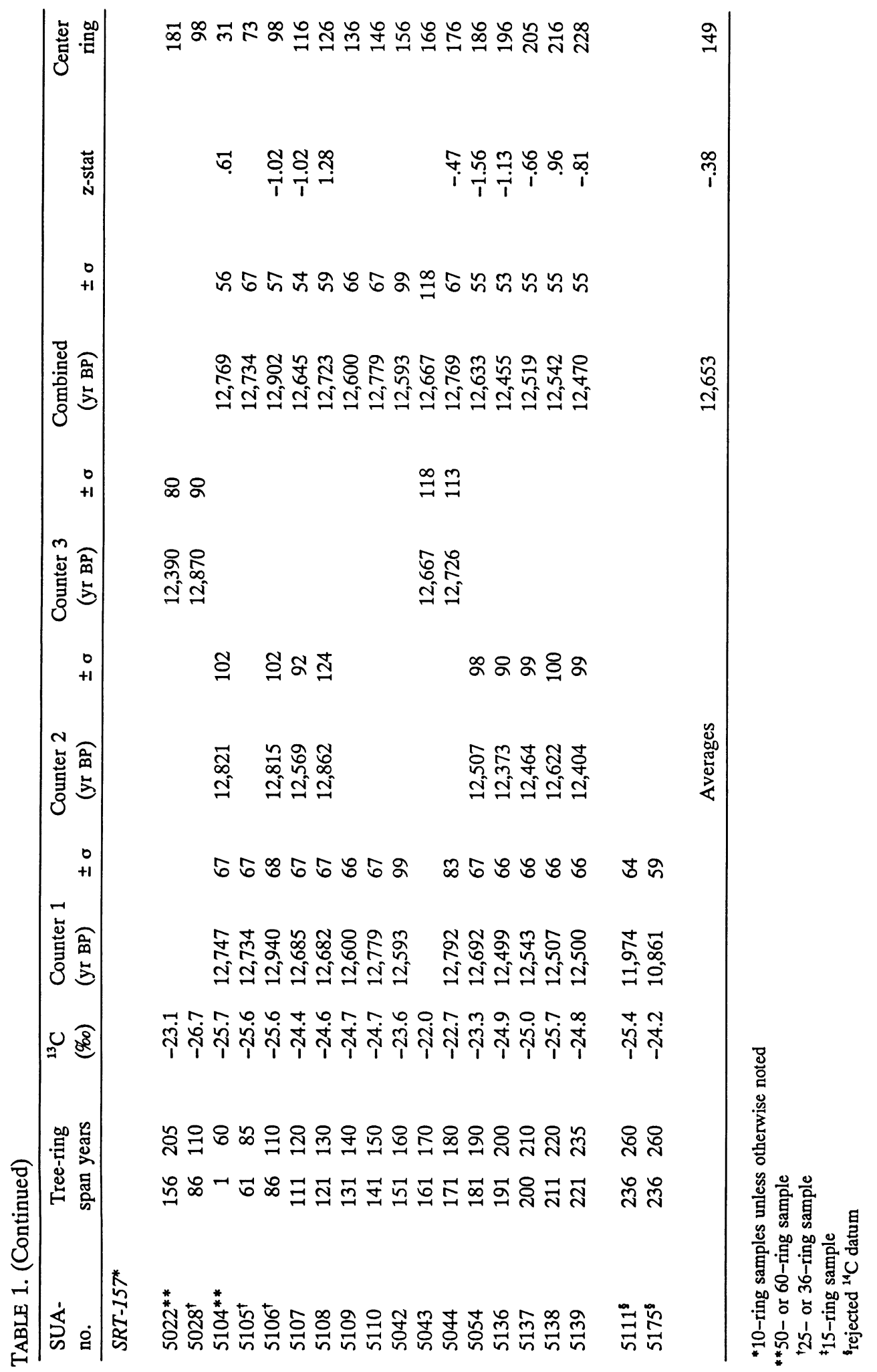




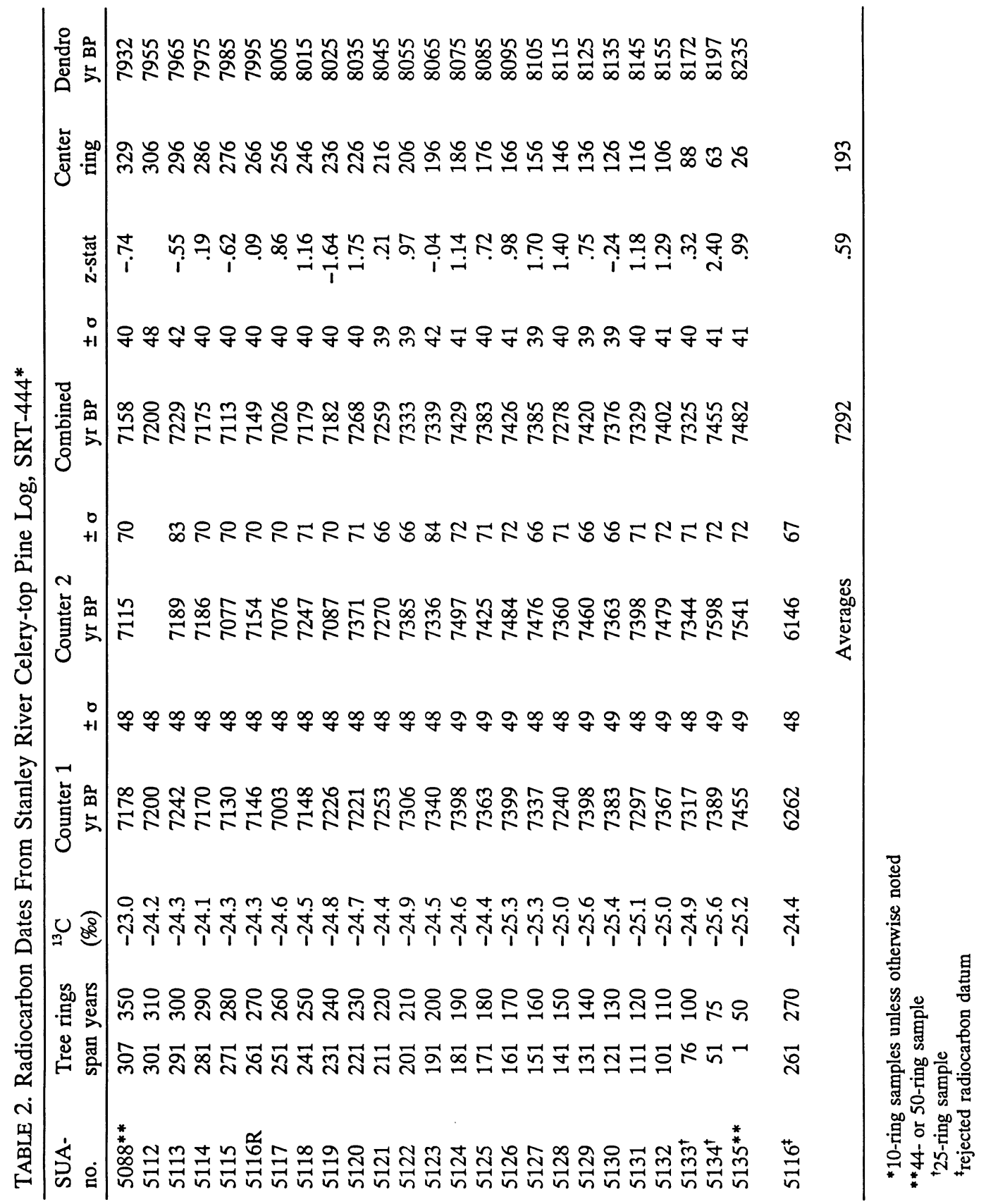



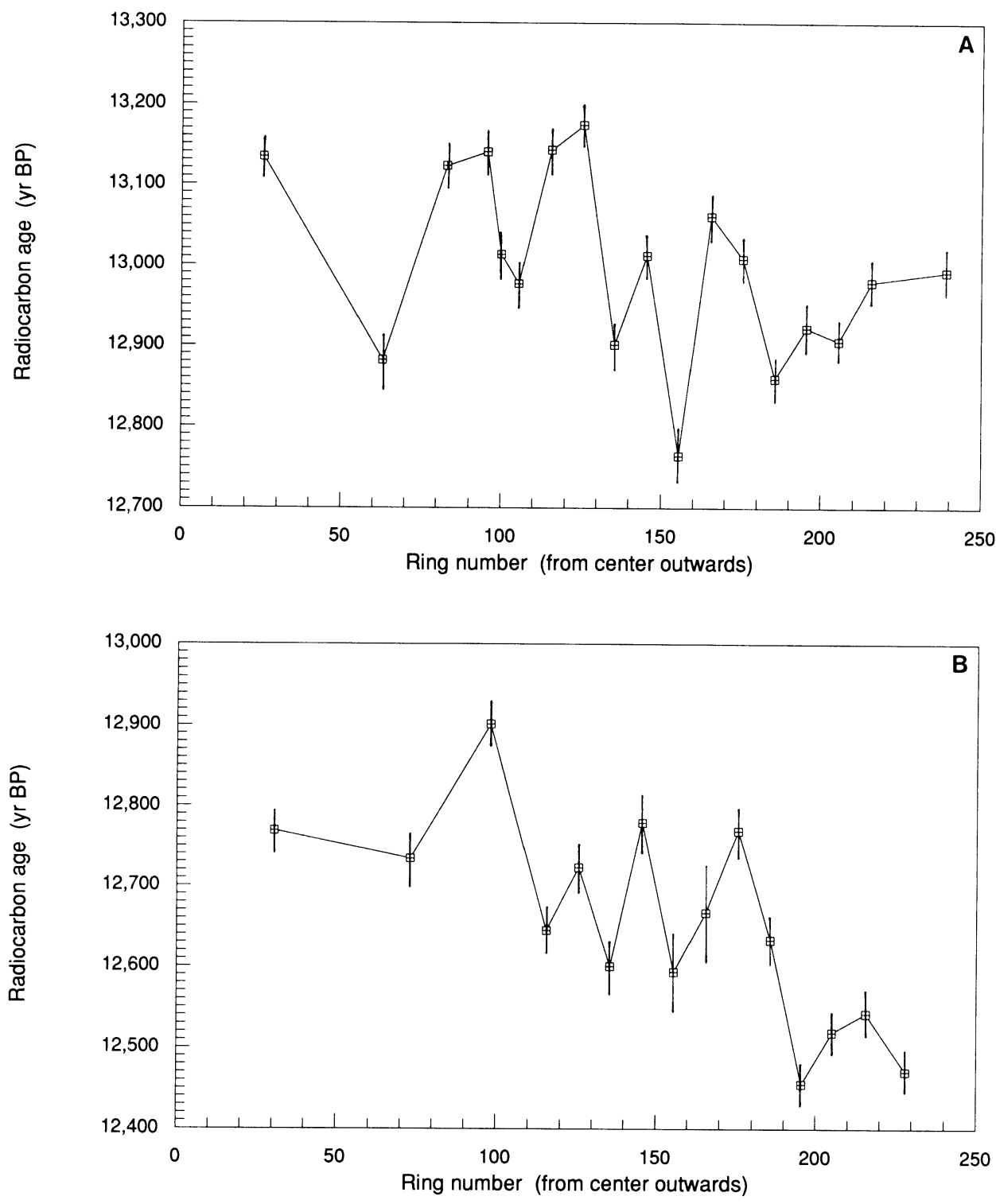

Fig. $1 .{ }^{14} \mathrm{C}$ ages from Stanley River celery-top pine logs, SRT-462 (A) and SRT-157 (B). The data are combined results from measurements in two liquid scintillation counters.

droyears BP. At that position, the SRT-444 data were an average of 14 yr younger than the oak data, with an rms difference of $61 \mathrm{yr}$. We also examined the robustness of the fit by adding or subtracting an arbitrary 50 or $100 \mathrm{yr}$ to all the SRT-444 ${ }^{14} \mathrm{C}$ data, but did not find a better fit. The bristlecone pine data covered only part of the region of interest, and was insufficient to allow a formal fitting procedure.

Results for the period, AD 1600-1800 (SRT-31B and SRT-225 in Table 3), indicated small systematic differences between the counters. The results from Counter 3 (measured 1986/87) were generally older than those from Counter 1, whereas the results from Counter 2 (measured 1987/88) 



Fig. 2A. Rms differences between the ${ }^{14} \mathrm{C}$ ages measured for SRT-444 and a smoothed (decadal) representation of the German oak data. The minimum difference occurs when ring 0 of SRT-444 is placed at $8260 \mathrm{yr}$ BP. Adding or subtracting an arbitrary 50 or $100 \mathrm{yr}$ to all the SRT-444 ${ }^{14} \mathrm{C}$ data gives a poorer fit between the data sets.
Fig. 2B. ${ }^{14} \mathrm{C}$ ages from Stanley River celery-top pine log, SRT-444 (--); combined results from two counters. The measurements are compared with data from the unified German oak series with ring 0 placed at $7230 \mathrm{BC}$, i.e., $9179 \mathrm{BP}$ (Kromer et al. 1986; - ) and a smoothed representation of the German oak data (- -). SRT. 444 is shown with ring 0 placed at $8260 \mathrm{yr} \mathrm{BP}$, which gives the best match to the German oak data. Bristlecone pine data from the USA (Linick et al. 1986; IIII) are also shown.

were younger. The results from Counter 1 alone are therefore used in Figure 3, where they show good agreement with the high-precision decadal data of Stuiver and Becker (1986). There are no significant differences in phase or amplitude of the variations. However, our data are, on average, slightly younger than the corresponding northern hemisphere data, and not older by ca. $36 \mathrm{yr}$, as would be expected from other comparisons of northern and southern hemisphere wood (Lerman, Mook \& Vogel 1970; Vogel et al. 1986). Since the northern and southern hemisphere measurements were made in different laboratories, we considered the possibility of an error in the modern standard determination in our laboratory. Thus, two of our pretreated wood samples were sent to Seattle for measurement; those results coincide with northern hemisphere data (Fig. 3).

\section{DISCUSSION AND CONCLUSION}

Comparisons of conventional ${ }^{14} \mathrm{C}$ ages with results from other dating methods provide data on ${ }^{14} \mathrm{C}$ calibration for the late Pleistocene. Uranium-thorium data have been published by Bard et al. (1990); varve data by Stuiver (1971) and Stuiver et al. (1986); and summaries of thermoluminescence data were given by Barbetti (1980) and Aitken (1987). These data are summarized in Figure 4. 


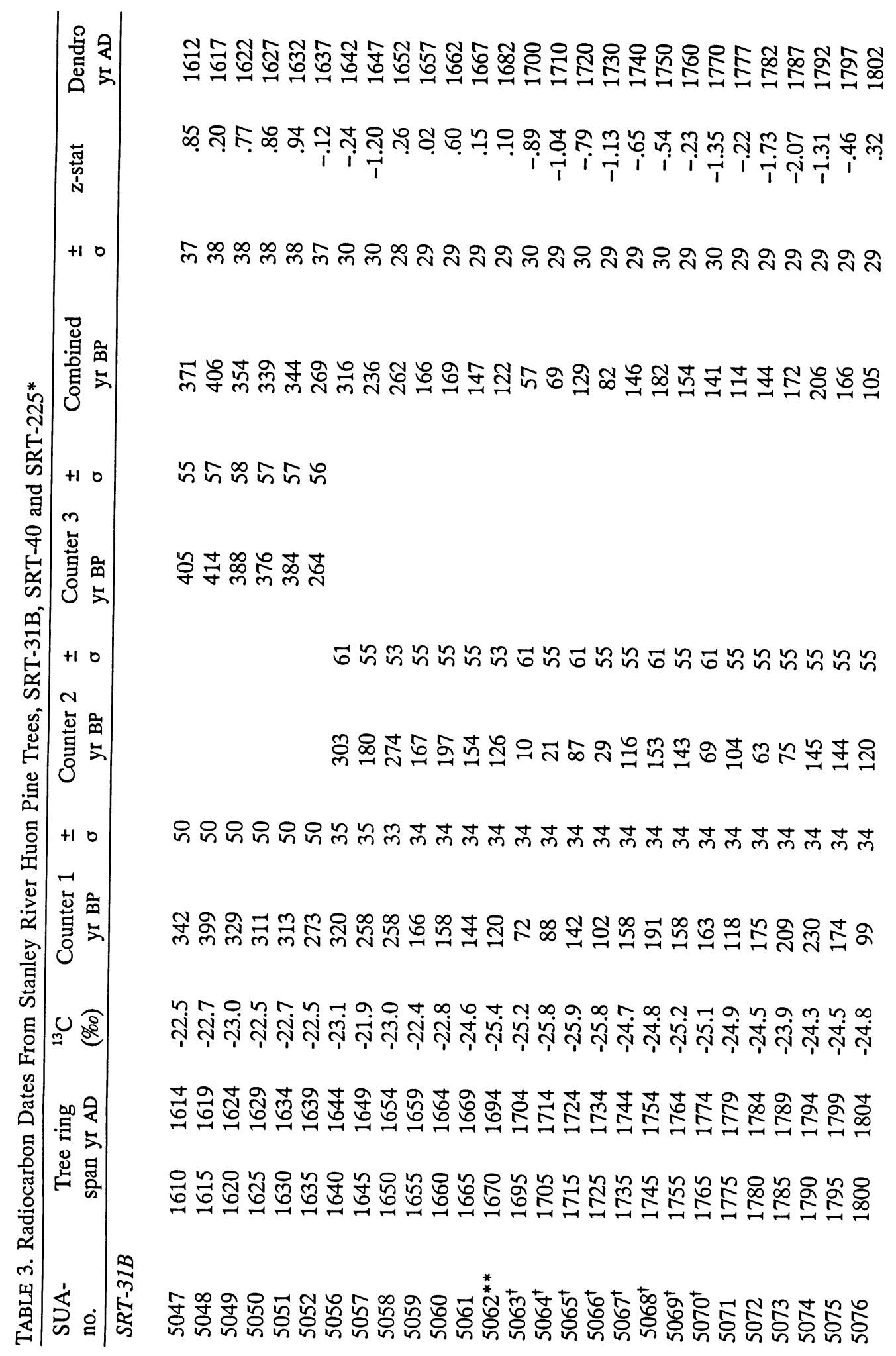




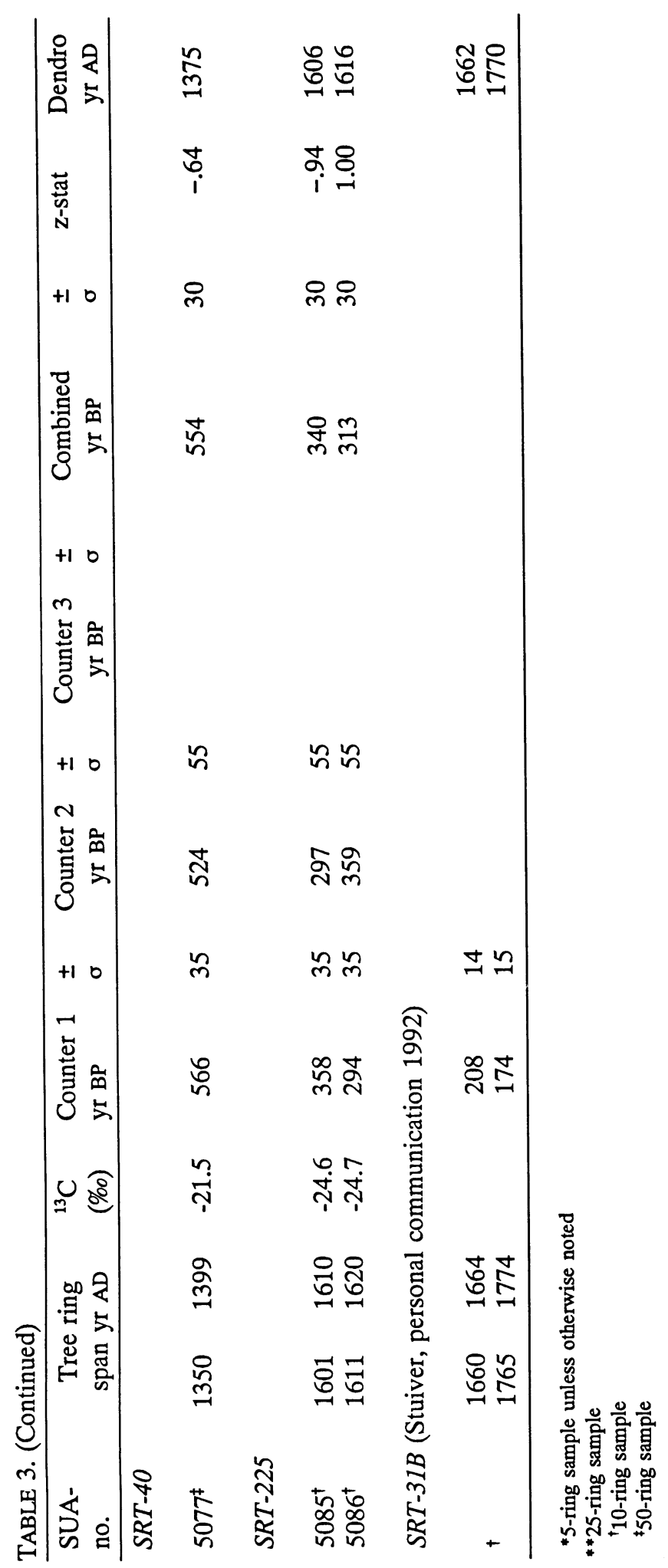




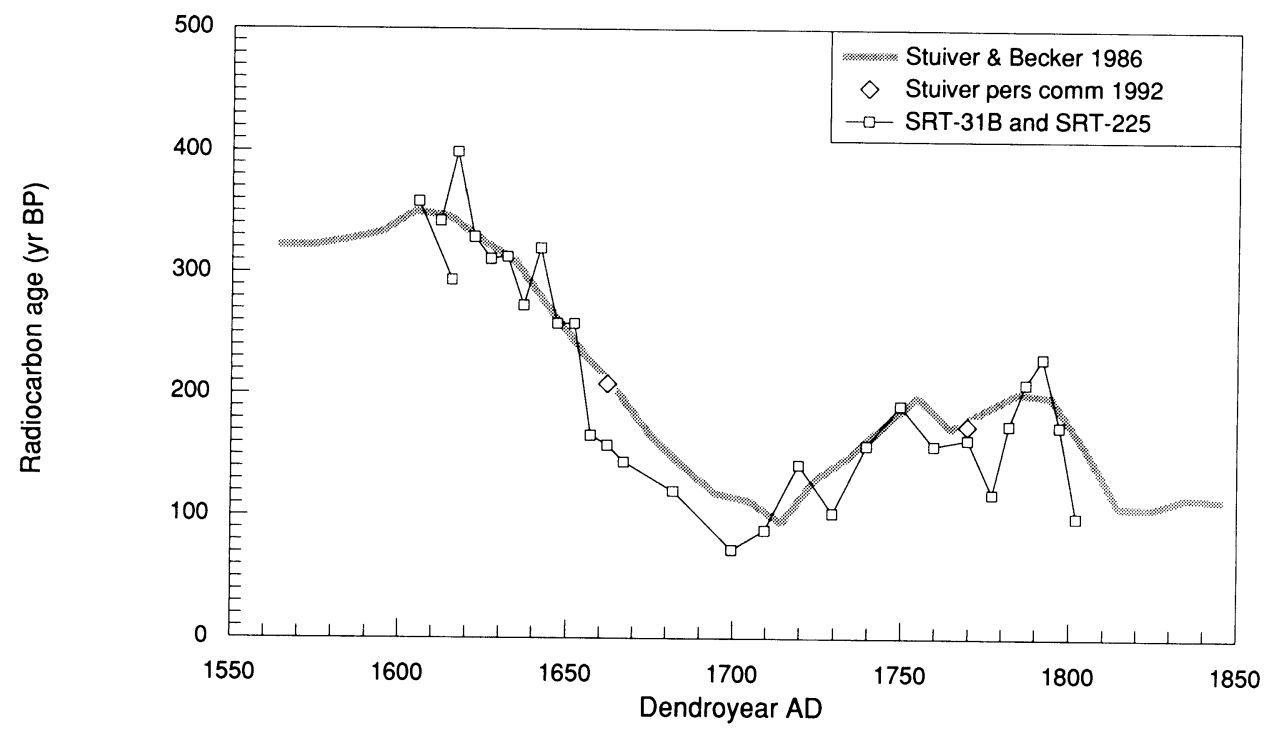

Fig. $3 .{ }^{14} \mathrm{C}$ ages from Stanley River Huon pine trees, SRT-31B and SRT-225, for the period AD 1600-1800; Counter 1 data only. The results are compared with the high-precision decadal curve of Stuiver and Becker (1986). Two measurements were made on our samples by Minze Stuiver $(\diamond)$.



Fig. 4. Comparison of conventional ${ }^{14} \mathrm{C}$ ages with other dating methods for part of the late Pleistocene and early Holocene. The solid line would be the ideal relationship if conventional ${ }^{14} \mathrm{C}$ ages were always equal to true ages, and the dashed line shows the deviation expected for the 5568-yr half-life. The U-Th data are from Bard et al. (1990), the varve data from Stuiver (1971) and Stuiver et al. (1986), and the TL data from Barbetti (1980) and Aitken (1987). ${ }^{14} \mathrm{C}$ data from southern Germany (Becker \& Kromer 1986) are from a floating Preboreal tree-ring sequence, shown here on the assumption that the ${ }^{14} \mathrm{C}$ ages are, on average, $1 \mathrm{ka}$ too young (i.e., ring 0 for the Preboreal pine is tentatively placed at $9031 \mathrm{BC}$ or 10,980 BP). The Stanley River data from SRT-462 and SRT-157 are shown here on the assumption that ${ }^{14} \mathrm{C}$ ages are 2 ka too young. 
Virtually all data indicate that ${ }^{14} \mathrm{C}$ ages are younger than true ages during the late Pleistocene, with probable differences ranging from $2.6 \mathrm{ka}$ at $15 \mathrm{ka} \mathrm{BP}$ to $0.9 \mathrm{ka}$ at $10 \mathrm{ka}$ BP (Stuiver et al. 1991).

${ }^{14} \mathrm{C}$ data from the Stanley River and from German Preboreal pine (Fig. 4) show trend changes on a time scale of 1 or 2 centuries, such as those seen throughout the Holocene. The Preboreal data also show a plateau in the calibration curve with nearly constant ${ }^{14} \mathrm{C}$ ages (9600 BP) over several centuries in early Holocene time.

Tasmanian ${ }^{14} \mathrm{C}$ data from SRT-444 have been wiggle-matched with German oak data. With ring 0 of the oak data at 7230 BC (Kromer et al. 1986), our match places ring 0 of SRT-444 at 8260 dendroyears BP. With that match, our data appear to be slightly, but not significantly, younger than the northern hemisphere data.

Our data from the southern hemisphere for the period, AD 1600-1800, also indicate little or no offset in ${ }^{14} \mathrm{C}$ concentration when compared with northern hemisphere data. These minimal apparent offsets, at around $8.1 \mathrm{k}$ dendroyears BP, and again, in recent centuries, would provide an important constraint on global carbon models if confirmed by further measurements.

Detailed intercomparisons with other laboratories are being planned, and it should be possible eventually to estimate precisely the offset between the northern and southern hemispheres during early and mid-Holocene time.

\section{ACKNOWLEDGMENTS}

We thank the Forestry Commission, Tasmania, the Hydro Electric Commission of Tasmania, and Corinna Sawmills for logistical support in the field, and the Australian Research Council and the University of Sydney for financial support. We also thank Minze Stuiver for comparative measurements on two of our wood samples.

\section{REFERENCES}

Aitken, M. J. 1987 Archaeometrical dating: Rapporteur review. In Aurenche, O., Evin, J. and Hours, F., eds., Chronologies in the Near East. BAR International Series 379: 207-218.

Barbetti, M. 1980 Geomagnetic strength over the last 50,000 years and changes in atmospheric ${ }^{14} \mathrm{C}$ concentration: Emerging trends. In Stuiver, M. and Kra, R. S., eds., Proceedings of the 10 th International ${ }^{14} \mathrm{C}$ Conference. Radiocarbon 22(2): 192-199.

Bard, E., Hamelin, B., Fairbanks, R. G. and Zindler, A. 1990 Calibration of the radiocarbon timescale over the past 30,000 years using mass-spectrometric U-Th ages from Barbados corals. Nature 345: 405-410.

Becker, B. and Kromer, B. 1986 Extension of the Holocene dendrochronology by the Preboreal pine series, 8800 to 10,100 BP. In Stuiver, M. and Kra, R. S., eds., Proceedings of the 12 th International ${ }^{14} \mathrm{C}$ Conference. Radiocarbon 28(2B): 961-967.

Francey, R. J., Barbetti, M., Bird, T., Beardsmore, D., Coupland, W., Dolezal, J. E., Farquhar, G. D., Flynn, R. G., Fraser, P. J., Gifford, R. M., Goodman, H. S., Kunda, B., McPhail, S., Nanson, G., Pearman, G. I., Richards, N. G., Sharkey, T. D., Temple, R. B. and Weir, B. 1984 Isotopes in tree rings - Stanley River
Collections 1981/82. CSIRO Division of Atmospheric Research, Aspendale, Victoria. Technical Paper 4: $86 \mathrm{p}$.

Gupta, S. K. and Polach, H. A. 1985 Radiocarbon Dating Practices at ANU. Handbook, Research School of Pacific Studies, Canberra: 173 p.

Head, J. (ms.) 1979 Structure and chemical properties of fresh and degraded wood. M.Sc. thesis, Australian National University, Canberra: 103 p.

Kromer, B., Rhein, M., Bruns, M., Schoch-Fischer, H., Münnich, K. O., Stuiver, M. and Becker, B. 1986 Radiocarbon calibration data for the 6th to the 8th millennia BC. In Stuiver, M. and Kra, R. S., eds., Proceedings of the 12 th International ${ }^{14} \mathrm{C}$ Conference. Radiocarbon 28(2B): 954-960.

Lerman, J. C., Mook, W. G. and Vogel, J. C. $1970{ }^{14} \mathrm{C}$ in tree rings from different localities. In Olsson, I. U., ed., Radiocarbon Variations and Absolute Chronolo. gy. Proceedings of the 12th Nobel Symposium. New York, John Wiley \& Sons: 257-299.

Linick, T. W., Long, A., Damon, P. E. and Ferguson, C. W. 1986 High-precision radiocarbon dating of bristlecone pine from 6554 to 5350 BC. In Stuiver, M. and Kra, R. S., eds., Proceedings of the 12th 
International ${ }^{14} \mathrm{C}$ Conference. Radiocarbon $28(2 \mathrm{~B})$ : 943-953.

Stuiver, M. 1971 Evidence for the variation of atmospheric $\mathrm{C}^{14}$ content in the late Quaternary. In Turekian, K. K., ed., The Late Cenozoic Glacial Ages. New Haven, Connecticut, Yale University Press: 57-70.

Stuiver, M. and Becker, B. 1986 High-precision decadal calibration of the radiocarbon time scale, AD 19502500 BC. In Stuiver, M. and Kra, R. S., eds., Proceedings of the 12th International ${ }^{14} \mathrm{C}$ Conference. Radiocarbon 28(2B): 863-910.

Stuiver, M., Braziunas, T. F., Becker, B. and Kromer, B. 1991 Climatic, solar, oceanic and geomagnetic influences on late-glacial and Holocene atmospheric ${ }^{14} \mathrm{C} /{ }^{12} \mathrm{C}$ change. Quaternary Research 35: 1-24.

Stuiver, M., Kromer, B., Becker, B. and Ferguson,
C. W. 1986 Radiocarbon age calibration back to 13,300 years $\mathrm{BP}$ and the ${ }^{14} \mathrm{C}$ age matching of the German oak and US bristlecone pine chronologies. In Stuiver, M. and Kra, R. S., eds., Proceedings of the 12th International ${ }^{14} \mathrm{C}$ Conference. Radiocarbon 28(2B): 969-979.

Stuiver, M. and Pearson, G. W. 1986 High-precision calibration of the radiocarbon time-scale, AD 1950500 BC. In Stuiver, M. and Kra, R. S., eds., Proceedings of the 12 th International ${ }^{14} \mathrm{C}$ Conference. Radiocarbon 28(2B): 805-838.

Vogel, J. C., Fuls, A., Visser, E. and Becker, B. 1986 Radiocarbon fluctuations during the third millennium BC. In Stuiver, M. and Kra, R. S., eds., Proceedings of the 12th International ${ }^{14} \mathrm{C}$ Conference. Radiocarbon 28(2B): 935-938. 